\title{
Menelusuri Jejak Rupa Wayang Klasik Bali
}

\author{
I Dewa Alit Dwija Putra \\ Department of Visual Communication Design, School of Creative Industries \\ Telkom University
}

\begin{abstract}
The form of Balinese classical wayang 'puppets' through its long history, starting from primitive times, ancient Balinese, Balinese Hinduism, and colonialism until now. As a work of art of ancestral heritage with its various forms and developments, many Balinese people do not know the history of the puppet origins that became 'pakem' in its traditional art. To find out the traces of the classical wayang 'puppets' of Bali have similarities form with the depiction of puppets figures that exist in the temples of Central Java and East Java. The art crossed to Bali through the conquest of Bali during the Majapahit colonialism. This research uses historical method through heuristic stages, criticism, interpretation, and historiography, to be able to describe historically the origin of classical Balinese puppets as well as analysis matrix comparison to see the similarities and differences of Balinese puppets visual that exist in the temple the studies reliefs in the two areas. Wayang puppet as a form of art in Balinese society has all aspects of value, both material values, moral values, and spiritual values.
\end{abstract}

Keywords: visual, classical puppets, Bali

\section{PENDAHULUAN}

Kesenian Klasik Bali adalah kesenian yang diwariskan pada masa Bali Hindu Klasik, merupakan bagaian dari periodisasi sejarah perkembangan kebudayaan Bali yang dimulai dari jaman prasejarah (awal sampai $800 \mathrm{M}$ ), Jaman Bali Kuno (800-1300 M), Jaman Bali pertengahan (1400-1880 M), dan masa kolonial (1900 M) (Ardika, Parimartha, Wirawan, 2015). Pada jaman Bali pertengahan ini merupakan periode panjang pembentukan seni budaya Bali, yang dibaga lagi dalam beberapa jaman meliputi : jaman Jawa Hindu-Bali (13501460 M) dan jaman Bali Hindu klasik (1460-1550M).

Pada masa Jaman Jawa Hindu - Bali (1350-1460M) merupakan era kekuasaan kerajaan Majapahit di Bali. Selama Bali dijajah oleh Majapahit unsur-unsur budaya Hindu Jawa sangat kuat mempengaruhi sosial budaya masyarakat Bali, akulturasi yang terjadi menghasilkan sintesa harmonis Hindu Jawa dan Hindu Bali menjadi seni budaya Bali yang bernuansa Majapahit. Runtuhnya kerajaan Majapahit akibat 
masuknya Islam di di Jawa (1400 M) kekuasaan Majapahit di Bali pun semakin lemah dan Bali menjadi wilayah yang merdeka, dengan pusat kerajaan di wilayah Gelgel Klungkung. Pembinaan seni-budaya terutama bidang kesusastraan mendapat tempat yang penting sehingga pada masa pemerintahan Dalem Waturenggong sekitar tahun 1460 - 1550 Masehi, kesenian Bali mencapai puncak kejayaan atau keemasannya. Pada masa tersebut kesenian Bali juga disebut kesenian Bali klasik. Kesenian klasik inilah yang menjadi 'pakem' atau tolak ukur kesenian tradisional masyarakat Bali hingga sekarang. Kata pakem merupakan semacam konvensi aturan yang telah terbangun secara turun-temurun baik mengenai pembuatan maupun secara pertunjukan ( Irfansyah, 2013 : 206).

Salah satu kesenian klasik tersebut adalah kesenian wayang yang telah mengalami perkembangan pesat bersama kesenian lainnya seperti tari, musik, seni rupa, sastra dan lain sebagainya. Wayang lebih dikenal lewat seni pertunjukan memilki semua aspek seni tersebut seperti musik (kerawitan), seni suara (kidung atau kawih) dan seni rupa berupa perwujudan figurfigur wayangnya. Apa yang disebut wayang klasik dalam masyarakat Bali memang tak dapat dilepaskan dari warisan perwujudan wayang purwa yang dikenal tersebut. Citra wayang selalu tertuju pada pertunjukan bayangan dengan tokoh-tokoh yang tak asing dari epos cerita Mahabharata dan Ramayana, demikian juga dengan karakter penokohan dari cerita-cerita rakyat yang ada dalam masyarakat Bali.

Seiring dengan perkembangan jaman akibat kemajuan pengetahuan dan teknologi, kesenian wayang juga mengalami adaptasi dan penyesuaian agar tidak ditinggalkan oleh penggemarnya. Dalam seni pertunjukan wayang, dalang sebagai aktor utama mengadaptasi hal tersebut dengan menciptakan atau menyisipkan tokoh atau karakter baru pada pementasannya. Biasanya tokoh-tokoh ini sebagai banyolan atau lawakan yang muncul bersama parekan (punakawan). Penggunaan lampu digital pengganti 'blencong' (lampu minyak) dan audiovisual memberi pertunjukan wayang kulit lebih atraktif dan modern. Agar pesan cerita dapat tersampaikan kesemua khalayak sasaran, penggunaan bahasa Indonesia dan asing bercampur dengan bahasa Bali Kuno atau Kawi sebagai media komunikasi yang menghidupkan pertunjukan kesenian wayang tersebut.

Keberadaan wayang klasik atau purwa yang sampai saat ini tetap berlangsung sebagai suatu kesenian tradisional dalam masyarakat, dikarenakan masyarakat Bali masih taat akan adat dan kepercayaannya yang didasari oleh Agama Hindu. Adanya pertunjukan kesenian wayang biasanya mengikuti rangkaian upacara tertentu dalam masyarakat Bali, apakah upacara untuk persembahan kepada Tuhan disebut Dewa Yadnya, untuk orang suci disebut Resi Yadnya, untuk manusia disebut Manusia Yadnya, untuk leluhur disebut Pitra Yadnya, sedang untuk makhluk alam bawah disebut Bhuta Yadnya. Namun sekarang wayang juga dipentaskan sebagai seni pertunjukan biasa.

Terdapat dua jenis seni pertunjukan wayang di Bali yaitu pertunjukan yang diadakan malam hari disebut Wayang Peteng dan pertunjukan yang diadakan 
siang hari yang disebut Wayang Lemah. Wayang lemah, ini termasuk seni pertunjukan yang khusus artinya pementasan hanya dapat dilakukan pada waktu dan upacara tertentu seperti untuk ruatan. Sebagai contoh apabila ada orang yang lahir tepat di Tumpek Wayang, anak tersebut harus diruat dengan menggunakan pertunjukan wayang lemah. Pertunjuka ini tidak menggunakan klir atau layar seperti pada pertunjukan wayang umumnya. Hanya menggunakan seutas benang dan uang kepeng yang dibentangkan di pohon dadap.

Wayang dalam seni pertunjukan pada masyarakat Bali memiliki berbagai bentuk kesenian, seperti wayang wong (orang), wayang kulit, wayang gedok, wayang lemah, wayang cupak, wayang sapuleger, wayang sudamala, calonarang dan lain sebagainya. Kata dibelakang yang mengikuti wayang dapat mengidentifikasi tema atau penggambaran tokoh wayang. Misalnya wayang calonarang, merupakan wayang dengan tokoh-tokohnya diambil dari cerita tersebut, dengan latar jaman kerajaan Kediri. Wayang cupak, wayang ini tokoh utamanya adalah Cupak yang memiliki saudara kembar bernama Gerantang dengan tabiat perilaku yang bertolak belakang. Disamping itu jenis gamelan atau tatabuhannya pun memilki ciri kekhasan masing-masing dalam pementasannya.

Wayang Wong adalah suatu seni pertunjukan wayang dimana pelakunya adalah manusia (wong) yang menggunakan topeng dengan tipologi perwajahan wayang. Kelompok wayang wong di Bali lebih banyak mengambil cerita Ramayana dengan bentuk tipologi wajah muka kera seperti tokoh Hanoman,
Anggada, Jembawan dan lain sebagainya, semuanya merupakan pasukan Sri Rama dalam merebut kembali Dewi Sinta yang di tawan oleh Rahwana. Kesenian ini dikategorikan jenis kesenian sakral, dipentaskan pada hari dan upacara tertentu. Kelompok keseniann wayang wong sangat popular dikalangan masyarakat Bali Utara.

Kesenian wayang dalam masyarakat Bali, selain popular dalam seni pertunjukan juga popular dalam seni rupa, seperti seni lukis, patung dan pada ragam hias. Pada seni lukis wayang berfungsi untuk menghiasi 'parba' dan 'pengider-ider' pada bangunan pura. Pada bentuk seni patung lebih banyak untuk menghiasi bangunan pura-pura sesuai arah mata angin atau simbol dewata nawasanga. Figur wayang klasik juga dipahatkan pada tembok pura berpadu dengan pola ragam hias tradisional Bali dengan tema yang tak asing yaitu Mahabharata dan Ramayana.

Wayang 'Klasik,' kata 'klasik' memiliki pengertian dari Kamus Besar Bahasa Indonesia 'klasik' berarti : tertinggi, mempunyai nilai/mutu yang diakui dan menjadi tolak ukur kesempurnaan yang abadi (Tim Penyusun, 1999). Lebih lanjut dijelaskan arti 'klasik' berasal dari kata 'kelas' bermakna terbaik, puncak, paling sempurna sesuai dengan 'pakem' baku dalam penciptaan. Dari dua pengertian 'klasik' tersebut didapat suatu kesimpulan yang tertinggi dan dijadikan patokan ukuran, dalam hal ini patokan yang dimaksud adalah perupaan atau bentuk figur wayang. Demikian juga halnya bentuk atau wanda, ikonografi, yang didasarkan pada tipologi pembentukan wajah seperti : halus, keras (aeng), lucu dan lain-lainnya (Nilotama, 
2012 : 145). Di Bali rupa wayang menunjukan persamaan watak atau tipologi dengan wayang kulit di Jawa (masa Islam), hanya saja dari penggayaan wayang Jawa lebih deformatif memiliki stilasi yang berlebih sehingga menjauh dari bentuk natural di banding wayang Bali yang naturalistik. Penggambaran tipologi wayang kulit juga memiliki kesamaan dengan perwatakan yang terdapat pada karya rupa topeng. Tipologi perwatakan tersebut seperti 'manis', 'aeng', 'keras', 'galak' dan lucu (bondres) (punakawan).

Mengenai asal-usul kesenian wayang di Bali maupun di Indonesia masih menjadi perdebatan para ahli. Ada yang mengatakan wayang merupakan bentuk kesenian asli Indonesia, ada ahli yang menyatakan wayang dari India, ada juga yang menyatakan dari Cina. Hal tersebut didasarkan bagaimana dua kebudayaan tersebut merupakan penyumbang besar kebudayaan Indonesia masa HinduBuddha. Agama Hindu di Bali merupakan agama mayoritas masyarakatnya, tentunya tak dapat dihindari ajaran-ajaran yang ada padanya memberi pengaruh kedalam keseniannya.

Perupaan Wayang Klasik di Bali disinyalir memiliki kedekatan rupa dengan penggambaran karakter yang ada di relief-relief candi Jawa Timuran. Kedekatan ini ditinjau dari sejarah bahwa Bali memilki hubungan dengan kerajaankerajaan yang ada di Jawa Timur seperti Majapahit. Ada juga ahli yang menduga bahwa perupaan wayang Bali tidak hanya dekat dengan rupa wayang yang ada di relief Jawa Timur tapi juga pada relief yang ada di Jawa Tengah. Hubungan kerajaan Bali dan Jawa Timur tersebut sudah dimulai abad ke 10, masa raja Erlangga yang merupakan anak dari Udayana yang memerintah di Bali (Yudoseputro, 2008 : 124).

Namun kesenian wayang berkembang begitu pesat di perkirakan pada abad ke13 masa kejayaan Majapahit. Pada waktu Majapahit mengalami kemundurun akibat masuknya Islam, kerajaan Bali seakan mendapatkan kebebasan dan kesenian di Bali berkembang pesat dan mencapai puncak keemasanya pada masa pemerintahan Dalem Watu Renggong di Abad ke-14, yang mendasari kesenian tradisional Bali hingga sekarang. Pada waktu masa kolonialisme Belanda di Bali kesenian wayang juga tetap mendapat perhatian dan perlindungan oleh pemerintahan Hindia Belanda. Belanda menjadikan Bali sebagai museum hidup dengan program Balinisasinya 'Balishering' masyarakat Bali diminta kembali ke kesenian Majapahitnya. Kebijakan tersebut berbenturan dengan politik itis yang dikeluarkan oleh kolonial.

Adanya perbedaan para ahli mengenai asal-usul rupa wayang Bali, apakah lebih dulu berkembang di Jawa Tengah ataukah di Jawa Timur atau di Bali sendiri. Hal ini tentunya dapat ditelusuri dari angka tahun, peninggalanpeninggalan benda, visual dan tematema cerita yang diangkat berkaitan dengan keberadaan prasasti-prasasti yang ditemukan di dua tempat tersebut. Penelusuran ini sangat menarik karena Jawa Tengah dan Jawa Timur pada era tersebut berada dalam kekuasaan kerajaan Majapahit.

Penelusuran secara histori mengenai rupa wayang Bali, dilihat dari peninggalan relief di wilayah Jawa Tengah dan Jawa Timur, serta melihat 
bagaimana kesenian wayang menjadi suatu kesenian yang popular di jamannya. Demikian juga bagaimana kesenian wayang yang ada di Jawa Timur dan Tengah sampai di Bali kemudian bertahan sampai sekarang dan menjadi pakem kesenian tradisional masyarakatnya. Faktor-faktor apa sajakah yang membentuk serta dapat menjaga kelestarian kesenian wayang tersebut dalam masyarakat Bali.

\section{METODE PENELITIAN}

Penulisan ini menggunakan metode penelitian sejarah mencakup empat langkah sebagai berikut, yakni : 1) heuristis, 2) kritik, 3) interpretasi dan 4) historiografi. ( Sulasman ,2014: 90). Tahap pertama heuristis adalah tahap mengumpulkan atau pencarian data baik dari sumber-sumber tertulis, lisan, artepak, mapun pengamatan. Sumber lisan yaitu wawancara kepada para ahli, pelaku kesenian, dan budayawan. Wawancara dilakukan pada pelaku kesenian seperti Dalang I Made Sija yang tinggal di Desa Bone kabupaten Gianyar Bali berkaitan dengan dunia pewayangan pada masyarakat Bali. Wawancara juga dilakukan dengan Jro Mangku Gede Pura Kehen Bangli, sebagai pemangku pura Kehen tempat prasasti yang menunujukan adanya kesenian wayang di Bali. Observasi dilakukan mengamati keberadaan rupa wayang di Bali terutama rupa wayang kulit yang digunakan baik dalam seni pertunjukan maupun seni rupa. Perupaan wayang kulit dengan melihat seperangkat wayang yang dimiliki oleh Dalang I Made Sija di Desa Bone Blahbatuh Gianyar. Tahapan kedua yaitu kritik, menuliskan dan mendeskripsikan sumber-sumber yang dianggap valid dan obyektif baik dari studi literatur maupun dari wawancara serta observasi. Demikian pula mendeskripsikan sumber visual dengan membandingkan kesamaan dan kemiripan rupa yang ada pada relief dengan rupa wayang kulit/klasik Bali.

Tahap ketiga interpretasi menghubungkan atau mencari benang merah dari hasil analisis data maupun analisi visual didasarkan hubungan sosial budaya masyarakat Bali dan Jawa pada masa lalu, yang berkaitan dengan kesenian umumnya dan khususnya kesenian wayang. Apa saja kesamaankesamaan dan perbedaan rupa wayang dengan figur yang ada pada relief candi. Tahap terakhir adalah historiografi menuliskan atau merangkaikan secara kronologis dan sistematis bagaimana kesenian wayang muncul dari jaman ke jaman, di dasarkan pada kedekatan rupa yang ada di relief candi di Jawa Timur yaitu candi Penataran dan candi Jago. Kemudian candi Ceto dan candi Sukuh di Jawa Tengah. Tidak hanya sekedar melihat kemiripan rupa relief dengan wayang tapi lebih jauh dapat pula mengungkap simbol-simbol dan makna wayang dalam sosial budaya dan kepercayaan masyarakat Bali. Untuk analisis visual menggunakan analisis matrik terdiri dari kolom dan baris dengan cara membandingkan atau mensejajarkan obyek penelitian melalui tolak ukur yang sama maka akan terlihat persamaan dan perbedaan visual yang dibandingkan. (Soewardikoen, 2013 : 50). Obyek visual diletakan dan disejajarkan pada kolom-kolom, baik itu figur-figur wayang yang ada di candi dengan rupa wayang klasik atau purwa yang ada di Bali sekarang. Dari hal tersebut akan didapat informasi-informasi mengenai kesamaan, maupun perbedaan rupa 
seperti kedekatan gestur, tipologi wajah, maupun atribut seperti hiasan kepala, pakaian, dan unsur lain yang mendekati visualisasi wayang klasik Bali.

\section{HASIL DAN ANALISIS}

\section{Pemahaman Wayang dan Klasifikasi Wayang Kulit Bali}

Kata 'Wayang' dalam bahasa Jawa berarti 'bayangan'. Dalam bahasa Melayu disebut 'bayang-bayang'. Dalam bahasa Aceh : 'baying'. Dalam bahasa Bugis : 'wayang' atau 'baying'. Akar kata dari wayang adalah 'yang'. Akar kata ini bervariasi dengan 'yung', 'yang' antara lain terdapat dalam kata layang 'terbang' doyong- 'miring', tidak stabil : royong -selalu bergerak dari satu tempat ke tempat lain ; 'payang-payingan' berjalan sempoyongan, tidak 'tenang' dan sebagainya. Jadi bahasa Jawa wayang yang mengandung pengertian "berjalan kian kemari, tidak tetap, sayup-sayup (bagi substansi) bayang-bayang" telah terbentuk pada waktu amat tua ketika awalan wa masih memiliki fungsi.( Mulyono, $1989: 10$ )

Lebih lanjut dijelaskan merupakan kreativitas masa lalu, merupakan alam kreativitas seni primitif. Perkataan wayang seperti berbicara masalah 'bayangan', bila bicara bayangan berarti harus ada 'cahaya' bicara mengenai cahaya harus ada 'sumber cahaya'. Sumber cahaya seperti matahari, lampu, pengertian lebih dalam sumber hidup Tuhan. Wayang asalnya masih rancu, ada yang menyatakan dari India atau produk Hindu-Jawa. Para ahli Indonesia lebih sepakakat mengikuti teori Hazeu yang menyatakan wayang berasal dari tradisi manusia purba untuk suatu upacara keagamaan untuk memuja arwah nenek moyang (Nilotama, 2013 : 14)

Artian yang paling luas kata wayang menjadi berarti sebuah pertunjukan dramatik, sebuah drama, sebuah tontonan, apakah para aktornya boneka atau manusia. Pengertian ini mencangkup pada kesenian wayang yang ada di Bali termasuk jenis wayang wong dan wayang kulit. Dalam artian sempit juga dijelaskan kata wayang mengacu pada bayangan. Suatu pertunjukan yang menggunakan semacam boneka yang mengutamakan bayangan. Peristilahan wayang di Indonesia "bayangan" begitu juga disebut di India kata-kata yang berbeda dipergunakan yang sekarang di interpretasikan berarti pertunjukan bayangan atau boneka pertunjukan bayangan mengambil istilah "rupparupaka" dari aturan-aturan bahasa Pali. Menunjuk teater dengan bonekaboneka kulit. (Holt, 2000 :167).

Wayang dalam seni pertunjukan jelas menggunakan 'klir' atau layar untuk menangkap banyangan. Selain itu pemeran utama dalam seni pertunjukan wayang kulit adalah 'dalang'. Pengertian diatas mencangkup satu jenis teater Bali tradisional yang sering dipentaskan dalam masyarakat Bali yaitu wayang kulit yang telah mengalami sebuah perjalanan sejarah yang hidup dalam mitos-mitos serta telah terjalin dengan kebudayaan luar seperti India dan Cina, dengan pola rupa yang telah dikenal selama ini.

Berkaitan dengan perupaan wayang kulit Bali yang dikenal dan menjadi "pattern" dalam seni pedalangan yang meneruskan tradisi kesenian Bali Hindu klasik yang memiliki kemiripan dengan perupaaan karakter yang ada dalam penggambaran 
relief-relief yang ada di Jawa Timuran dan beberapa candi yang ada di Jawa Tengah. Berkaitan tokoh-tokoh atau figur-figur berupa abdi-abdi yang berbentuk cacat, cebol, sangat gemuk, dan aneh sekali dari para ksatria, yang disebut panakawan. Penggambaran figur-figur relief yang meyerupai wayang kulit Bali ditunjukan penggambaran relief-relief pada candi Jago, Candi Penataran, Candi Kedaton, Surawana, Candi Tegowangi, Candi Singosari di Jawa Timur dan Candi Ceto serta Sukuh di Jawa Tengah. Pada bagian akhir dari abad ke-13 di Candi Jago, penggambaran wayang kulit menyajikan sebuah pola konvensional bagi perwujudan seni relief yang ada di Jawa dan Bali. Penjelasan ini mempertegas pengungkapan bahwa wayang kulit Bali memiliki kedekatan rupa dengan relief-relief yang ada pada candi tersebut.

Pemahaman berkesenian dalam masyarakat Bali berbeda dengan berkesenian dalam penegertian modern. Tidak ada istilah seni dan seniman. Aktifitas mereka melebur dalam upacara ritual masyarakatnya yang didasari oleh agama Hindu. Segala bentuk kesenian selalu mengacu pada kepentingan agama, didasari oleh kebersamaan dalam tata aturan adat istiadat.

Wayang pada seni pertunjukan di Bali diklasifikasikan pada lakon atau cerita yang dibawakan dibedakan menjadi : Wayang Parwa yaitu wayang yang hanya mempertunjukan cerita Mahabharata kata parwa merupakan pembabakan epos cerita tersebut yang dibagi dalam 18 parwa. Terdapat Wayang Ramayana yaitu wayang yang hanya memainkan kisah atau perjalanan Sang Rama dan Dewi Sita yang dibagi dalam tujuh Kanda.
Kemudian ada Wayang Calonarang, dalam pertunjukannya figur-figur wayang mengambil bentuk penokohan yang ada dalam cerita tersebut. Menceritakan ratu janda yang tinggal di desa Girah dengan latar kerajaan Kediri dan Jenggala. Wayang ini banyak mengandung nilai-nilai kehidupan dalam konsepsi masyarakat Bali disebut "rwa-bhineda" yaitu konsep falsafah hidup tentang keseimbangan cosmos seperti positif dan negatif, baik-buruk, baik-jahat dan lainnya, mencakup juga konsep keseimbangan estetik dalam berkesenian tradisional.

Berikutnya ada yang disebut dengan wayang Cupak, pertunjukan wayang yang menceritakan dua orang kakak beradik yang memiliki karakter atau tabiat yang berbeda. Cupak yang memilki rupa yang seram dengan sifat angkuh, sombong, gendut, ugal-ugalan, rakus dan sok tahu serta serampangan sangat berbeda dengan adiknya Gerantang yang cakep memiliki perawakan ideal dengan sifat-sifat yang baik. Sejenis dengan wayang Cupak adalah wayang Tantri, merupakan transformasi cerita fabel ke wayang kulit dengan tokoh-tokoh wayangnya mengambil karakter hewan. Tantri sendiri merupakan wanita desa yang di bawa ke istana untuk menghibur raja yang tidak bisa tidur. Wayang Tantri kemunculannya paling muda di Bali sekitar tahun 1978, diciptakan oleh seorang dalang dari Sukawati Gianyar yaitu I Wayan Wija. (Witari, 2009 : 16).

Selain itu terdapat juga wayang kulit hasil transformasi dari kesenian dramatari yaitu wayang Arja dan wayang Gambuh, lakonnya mengambil cerita malat (siklus Panji). Figur panji begitu banyak digambarkan di relief-relief Jawa 
Timuran, dengan sosok yang sangat khas dengan penutup kepala seperti topi. Disamping itu di Bali juga terdapat wayang Sasak. Wayang Sasak adalah wayang kulit yang populer di Lombok Barat dan masih di senangi dan sering dipentaskan di Kabupaten Karangasem Bali, biasanya mengambil tema Menak (cerita rakyat Lombok Amir Hamsah).

Wayang kulit juga diklasifikasikan berdasarkan penokohan antara lain : Pertama para makhluk surgawi yang tinggi moralitasnya seperti para dewa dan bidadari. Kelompok yang kedua disebut kasta tinggi seperti para brahmana, satria, dan wesya. Satria merupakan jumlah terbesar dalam kelompok ini, sebagai penyumbang terbesar dari cerita Mahabratha yaitu Pandawa dan Seratus Kurawa. Kelompok ketiga adalah Sudra, golongan pelayan, parekan (panakawan) atau penasar merupakan karakter penokohan dari rakyat. Mereka sering digambarkan kasar, aneh, lucu sejalan dengan karakter mereka dalam pertunjukan. Maka munculah karakter panakawan seperti Twalen, Meredah, Delem dan Sangut. Kelompok ke-empat adalah para raksasa, dari golongan denawa memilki karakter kasar, seram, liar, serakah dan dikegorikan dalam golongan jahat. Tokoh ini biasanya digambarkan dengan mata 'dedeling' bulat melotot dengan gigi bertaring, dan bagian atas pipi tumbuh taring yang disebut 'dangastra'. Kelompok terakhir yang disebut pendukung seperti ragam hias pemandangan yang disebut kekayonan atau sejenis gunungan yang berfungsi sebagai pengganti ruang dan waktu serta juga sebagai simbol pohon kehidupan atau hayat (cosmis). Selain itu terdapat figur-figur hewan dan kendaraan. Jumlah figur atau boneka wayang kulit dalam satu kropak (peti) menurut Hobart secara standar berjumlah sekitar seratus buah (Witari, 2009 : 17)

Semua jenis wayang yang didasarkan lakon tersebut di Bali memiliki tiga fungsi utama yaitu sebagai sarana upacara (wali), seni pertunjukan artistik (bebali), dan hiburan (balih-balihan). Karena bertujuan sebagai hiburan maka di dalamnya dimunculkan tokoh-tokoh jenaka seperti panakawan yang bertujuan sebagai penarik perhatian dan menghibur sehingga fungsi pertunjukan wayang sebagai dakwah tercapai. Rwa Bhineda adalah konsep masyarakat Bali tentang keseimbangan, baik keseimbangan cosmos, ragawi maupun rohani. Rwa Bhineda arinya dua hal yang berbeda tetapi tetap satu. Seperti contoh ada positif ada negatif, ada kanan ada kiri, dua hal tersebut di dunia ini tak dapat dipisahkan. Perwujudan ini dapat terlihat pada bentuk seni rupanya seperti pada ragam hias selalu dibuat kiri kanannya nampak sama tapi tak serupa.

Masyarakat Bali juga melihat atau memandang dunia ini dalam satu kesatuan, bahwa manusia buana alit bagian dari jagat raya buana agung. Serta menyakini tentang dunia yang tak nampak dan nampak 'Niskala' dan 'Sekala' bahwa diluar dari alam manusia terdapat alam lain yang berlapis. Konsepsikonsepsi masyarakat Bali tersebut dapat dilihat dari aktifitas mereka menjalankan upacara ritual keagamaan dan berkesenian. Dalam sebuah upacara keagaman misalnya hampir semua bentuk kesenian ada, tari, musik, sastra dan seni rupa. Hal yang berkaitan dengan rupa wayang seperti topeng, pengiderider, umbul-umbul, dan bentuk-bentuk sajen. 


\section{Prasasti dan Relief Candi}

Asal-usul wayang di Indonesia yang masih menjadi perdebatan para ahli, apakah wayang merupakan hasil asli bangsa Indonesia atau merupakan pengaruh dari kebudayaan India dan Cina ataukah kebudayaan lain. Untuk menunjukan hal tersebut kita dapat memaparkan dari sejarah keberadaan wayang. Di Indonesia wayang diperkiraan sudah ada sejak jaman kuno atau primitif, bentuk wayang masih sederhana dimana kepercayaan nenek moyang masih menganut animisme dan dinamisme. Kesinambungan ini terus berlanjut hingga masa kerajaan-kerajaan di Nusantara, di mana perupaan wayang atau kesenian wayang banyak digambarkan pada peninggalan reliefrelief bangunan candi. Baik itu kumpulan candi yang ada di Jawa Tengah maupun di Jawa Timur. Di Bali peninggalan relief yang memiliki figur wayang seperti pada relief candi di Jawa Timuran adalah satusatunya relief yang ada di Pura Taman Sari Kabupaten Klungkung yang dibangun sekitar abad ke-16 dan ke-17. Bukti-bukti berkaitan dengan kesenian wayang berupa catatan tertulis seperti prasasti, lontar-lontar, serta arca-arca yang tersebar di wilayah Bali. Mengenai perupaan wayang mengacu pada peninggalan relief candi yang ada di Jawa Timur dan Jawa Tengah untuk dibandingkan dengan perwujudan wayang kulit yang ada sekarang di Bali. Sejauhmana kedekatan dan kemiripan bentuk tersebut dari jaman kuno hingga sekarang. Beberapa prasasti yang digunakan para ahli untuk keberadaan kesenian wayang yang ada di Bali dan Jawa seperti prasasti yang ditemukan di desa Bebetin (Singaraja) pada masa pemerintahan raja Ugrasena berangka tahun ( 896 masehi) atau berangka tahun saka 818 saka. (Monografi Bali, 1985 :11) Menyebutkan kata-kata partapukan, parrbwayang, panekan, dihyang yang mengindikasi pertunjukan wayang dan topeng, juga ditunjukan dalam prasasti Dawan (Klungkung) berangka tahun 975 saka.

Wayang tidak sekedar pertunjukan hiburan tetapi lebih bersifat kejiwaan dan memberikan predikat bentuk klasik tradisional yang berdimensi dan berfungsi ganda yang dalam masyarakat Bali disebut pertunjukan utamenglungguh kedudukan terhormat. Wayang kulit di Bali sebagai nenek moyang teater tradisional Bali. terdapat unusr-unsur nilai seni, hiburan, pendidikan, pengetahuan, filsafat dan agama (Covarrubias, 2013 : 264)

Wayang tertua yang terdapat di Bali berupa releif pada perunggu menggambarkan Semara Ratih. Sejak tahun 1071 masehi. Relief ini tersimpan bersama dengan prasasti Anak Wungsu. Bukti wayang lainnya berupa lukisan Bhatara Guru yang dilukiskan pada prasasti Bhatara Guru tahun 1204 Masehi. Saat ini tersimpan Pura Kehen, Bangli (Personal interview : Mangku Gede Kehen, 6 Februari 2018). Hal lain yang menunjukan adanya kesenian wayang adalah prasasti Gurun Pai dari Desa Pandak Bandung, dikeluarkan oleh raja Anak Wungsu berangka tahun 1071, terdapat kata-kata seperti amukul (pemukul tabuh), anuling(seruling), atapuken (topeng), abanwal (penakawan), pirus (badut), menmen (tontonan), aringgit (wayang) (Bandem, 1985 : 21)

Keberadaan bukti tertulis mengenai wayang di Jawa di tulis oleh Krom, memperkirakan sumber paling mungkin 
bahwa pertunjukan bayang di daerah Jawa dan Bali yang memperoleh pengaruh kuat Hindu datangnya dari India. Hal tersebut didasarkan Jawa dan Bali terletak di Jalur perdangan yang strategis. Ini diungkap dalam prasasti yang dikeluarkan oleh Maharaja Sri Lokapala pada tahun 840 Masehi, tiga jenis kesenian tersebut tertuang dalam istilah atapukan, aringgit, dan abanol atau lawakan (Hotl, $2000: 165$ )

Pertunjukan 'wayang' di Jawa Tengah berasal dari tahun 907 Masehi, yang dikeluarkan oleh raja Balitung menyebut mawayang yaitu pertunjukan wayang. Pertunjukan wayang diperkirakan sudah ada dengan bukti pernah dipertunjukan wayang dengan mengambil cerita Bimmaya Kumara sebuah cerita tentang Bima. Prasasti ini menjelaskan bahwa awal abad ke-10 selain wayang sudah ada kesenian lain seperti tari, nyanyian, dan lawakan, serta penggunaan cerita Ramayana dan Mahabratha.

Bukti secara visual bagaimana bentuk rupa wayang Bali yang digambarkan tersebar di relief -relief candi yang ada di Jawa baik itu di Jawa Tengah maupun Jawa Timur. Candi di Jawa Tengah seperti candi Prambanan tidak begitu banyak menunjukan penggambaran figur-figur wayang klasik yang ada seperti di Bali. Langgam relief candi Prambanan sangat kental pengaruh India Guptanya. Figur- figur yang digambarkan begitu halus dan realistik, belum menggambarkan figur seperti wayang Bali. Walaupun Ramayana menjadi tema pada candi tersebut disamping ada penggambaran dewadewa dalam mitologi Hindu.

Relief-relief di Jawa Tengah yang menunjukan kedekatan dengan rupa wayang Bali adalah relief candi Sukuh dan Ceto terletak di lereng Barat Gunung Lawu berada di Desa Karanganyar, Magetaan Jawa Tengah. Candi yang diperkirakan di bangun pada masa akhir kerajaan Majaphit ini, memilki keunikan bentuk seperti bangunan piramid suku maya di Mexico. Bentuk bangunannya seperti punden berundak yang terpotong bagian puncaknya. Candi Sukuh dan candi Ceto diperkirakan berdiri pada tahun 1397 Saka atau 1475 Masehi, dibangun pada kekuasaan Majapahit akhir masa pemerintahan Brawijaya V.

Candi Sukuh dan Ceto digolongkan dalam candi Hindu-Siwa dimana bentuk arca-arca, relief-relief dan ornamen penghias candi menggunakan cerita dan bentuk-bentuk simbol yang ada dalam mitologi Hindu seperti lingga(phallus)yoni, dewa-dewa Hindu, penjaga, arca lembu, gajah, garuda, dan kura-kura seperti cerita dalam Brahmanda Purana. Sementara itu, relief cerita yang dipahatkan pada candi Sukuh, merupakan cerita Sudamala, Garudeya, Samudramanthana, pandai besi, dan Nawaruci. Pada candi Ceto, relief cerita yang dipahatkan merupakan penggalan cerita Sudamala, dan relief yang belum teridentifikasi (Saringendyanti, 2008 :25)

Penggambaran yang memilki kemiripan perupaan wayang Bali di jumpai pada relief-relief candi di Jawa Timur seperti pada candi Penataran, candi Jago, candi Jawi, candi Singosari, candi Tegowangi, candi Surawana dan candi Kedaton dan lainnya. Banyaknya relief-relief yang memiliki penggambaran wayang di daerah tersebut, ini menunjukan bahwa wayang merupakan suatu kesenian yang sangat popular dijamannya dengan berbagai bentuk dan fungsinya. Candicandi tersebut di bangun dari sekitar abad ke-13 hingga ke-15 Masehi dari 
masa pemerintahan Majapahit awal (Singosari) hingga mundurnya kerajaan tersebut karena masuknya pengaruh Islam. Candi-candi tersebut digolongkan dalam candi Hindu-Buddha yang dipengaruhi kuat oleh unsur kebudayaan India dan Cina. Sintesa dan asimilasi kebudayaan tersebut berjalan harmonis dan menemukan identitas ke Indonesiaannya terlihat pada penggambaran figur-figur wayang yang berbeda dengan langgam yang dimiliki candi Prambanan Jawa Tengah. Relief candi di Jawa Timur sejak jaman Singosari kehilangan sifat plastisitas dan melepaskan perwujudan naturalistis. Muncul figur-figur yang pipih dua dimensional yang terkerat pisah satu sama lain dalam gaya yang kaku seperti perwujudan pada wayang kulit (Yudoseputro, 2008 : 109)

Candi Penataran. Terletak di Kecamatan Nglegok kabupaten Blitar. Dari beberapa prasasti yang tersimpan disana, diperkirakan candi tersebut dibangun pada masa Raja Srengga dari kerajaan Kediri sekitar tahun 1200 Masehi dan berlanjut digunakan sampai masa pemerintahan Wikramawardhana, raja Majapahit sekitar tahun 1415 Masehi atau tahun 1337 Saka terdapat pada dinding kolam belakang Candi Penataran. Angka tersebut merupakan angka tahun termuda di antara angka tahun yang terdapat di kompleks Candi Penataran. Masyarakat meyakini bahwa candi Penataran sebagai tempat pemujaan yang bertujuan untuk menangkal atau menghindar dari mara bahaya yang disebabkan oleh Gunung Kelud yang sering meletus. Kitab Negarakretagama yang ditulis oleh Mpu Prapanca juga menjelaskan bahwa Raja Hayam Wuruk, yang memerintah kerajaan Majapahit antara tahun 1350 - 1389 pernah melakukan perjalanan ke Candi Palah untuk melakuka pemujaan, yaitu kepada Hyang Acalapat, perwujudan Siwa sebagai Girindra (Pratiwi, 2016 : 27)

Candi Jago terletak di daerah Malang juga memiliki perupaan relief seperti wayang yang ada di Bali. Candi ini dikenal dengan sebutan candi Tumpang dalam Pararaton dan Nagarakrtagama sebagai candi pendharman raja Wisnuwardhana atau Ranggawuni (Pararaton) atau Narrarya Seminingrat (Prasasti Mula-Malurung) sekitar tahun 1269 Masehi. Nama lain candi ini adalah Jajaghu yang merujuk pada nama desa atau tempat candi ini berdiri. Jajaghu adalah nama kuno untuk desa Jago sekarang. Candi Jago dikatakan berasal dari akhir Majapahit tetapi bahan-bahan batunya sangat mungkin berasal dari masa Singosari atau dari masa ketika direnovasi oleh raja Adityawarman dari Sumatra pada tahun 1343. Relief-relief di Candi Jago bisa dibagi dalam dua golongan. Relief yang bersifat Hinduistis dari Mahabaratha termasuk Parthayajna, Arjuna Wiwaha dan Kalayawana atau Krisna sementara yang bersifat reliefrelief Budhistis adalah Tantri, Aridharmma dan Kunjarakarna.

Candi-candi pada masa pemerintahan Majapahit di wilayah Jawa Timuran yang menggambarkan bentuk-bentuk wayang untuk hiasan reliefnya menunjukan bahwa media relief tidak begitu efektif dalam menyampaikan informasi terkait ajaran agama dan etika yang dilandasi agama. Karena candi merupakan tempat yang disucikan dan dijadikan tempat ritual keagamaan. Keberadaan gambar wayang yang ada pada relief jadi terbatas pada penikmatnya. Pengunjung hanya dapat melihat pada hari-hari tertentu 
atau adanya upacara. Oleh sebab itu gambar wayang pun dibuat pada kain dan daun lontar sejenis tanaman palem (kelapa), di Bali dikenal dengan 'lontar prasi'. Lontar 'prasi' merupakan komik tradisional Bali yang mirip dengan komik modern sekarang hanya dibedakan oleh media dan teknik pengerjaannya. Lontar prasi juga menggunakan figur-figur wayang seperti figur pada relief yang ada pada candi. Dalam prasi tidak seratus persen gambar ditampilkan, juga menyertakan tulisan seperti pada komik modern. Huruf yang digunakan adalah aksara Bali dengan Bahasa Kawi. Tradisi pembuatan lontar ini terkenal dalam dunia kesustraan Bali, demikian juga di Jawa.

\section{Kedekatan Rupa Wayang Klasik Bali dengan rupa figuratif Relief Candi Jawa Timur dan Jawa Tengah}

Berdasarkan pemaparan diatas bahwa kesenian wayang merupakan kesenian asli Indonesia yang memiliki proses pembentukan panjang. Dimulai dari jaman prasejarah bentuk kesenian yang menggunakan bayang-bayang sudah ada. Bahwa nenek moyang indonesia sudah mengenal kesenian bayangan sebagai kesenian primitif. Masuknya unsur-unsur pengaruh kebudayaan asing memberikan kekayaan bentuk dan tema pada kesenian tersebut. Serta bagaimana kearifan masyarakat lokal dalam mengolah dan mengantisipasi perkembangan tersebut.

Hubungan Bali dan Jawa sudah dimulai jaman raja Ugrasena tahun 896 Masehi dalam ikatan hubungan keluarga. Tetapi pada masa tersebut belum ada peninggalan dalam bentuk visual mengenai bentuk figur wayang. Hanya berupa prasati yang menyebutkan kata 'aringgit' Pada masa kekuasaan Majapahit, kesenian wayang lebih berkembang dan disempurnakan, terbukti dengan banyaknya peninggalan dalam bentuk visual berupa bentuk figurfigur wayang yang ada pada relief-relief candi di Jawa Tengah dan Jawa Timur.

Bukti-bukti tertulis yang menunjukan adanya kesenian tersebut di Jawa maupun di Bali menggunakan istilah yang sama untuk menunjukan wayang sebagai bentuk seni, baik seni tari, seni rupa maupun musik. Istilah-istilah tersebut seperti, amukul ( pemukul tabuh), anuling(seruling), atapuken (topeng), abanwal (panakawan), pirus (badut), menmen (tontonan), aringgit (wayang) demikian halnya angka tahun menunjukan bahwa kesenian wayang berkembang pada masa kerajaan Majapahit. Ketika majapahit mundur akibat masuknya Islam, kesenian wayang tetap berkembang di Bali hingga mencapai puncaknya pada masa Dalem Waturenggong abad ke-15 Masehi.

Proses panjang pembentukan rupa wayang kulit Bali melalui sebuah akulturasi yang harmonis. Rupa wayang Bali sepertinya dibawa dari Jawa pada masa Hindu-Budha dan berkembang pesat serta menjadi kesenian populer pada masa pemerintahan Majapahit sekitar abad ke-13 dan ke-14 Masehi. Kondisi tersebut banyak digambarkan pada relief-relief candi yang ada di jaman itu baik di Jawa Tengah maupun Jawa Timur. Kelompok candi di Jawa Tengah sebelum era Majapahit lebih banyak dipengaruhi oleh kepercayaan Budha dimana penggambaran figur-figur relief candinya menggunakan lagam Gupta atau India Selantan. Seperti pada relief di Candi Borobudur, Mendut dan Candi Sari. Sedangkan candi Prambanan 
sebagai candi Hindu banyak menggambarkan adegan-adegan cerita Ramayana. Kumpulan candi ini belum menampakan penggambaran figuratif wayang seperti di Bali. Figur-figur yang digambarkan masih realistik dengan corak realistik Indianya sangat kuat.

Sekitar abad ke-14 muncul candi Ceto dan Sukuh disekitar daerah Karanganyar, Surakarta, didirikan pada akhir pemerintahan Majapahit. Candi yang bernafaskan Hindu ini memiliki bentukbentuk simbol siwalistik dengan banyak penggambaran lingga-yoni, berupa pallus dan yoni yang besar-besar mengingatkan kita pada jaman megalitikum. Pada relief candi ini terlihat penggambaran figur-figur yang memiliki kemiripan dengan penggamabaran wayang yang ada di Bali. Demikian juga olahan cerita Mahabratha yang sudah di kemas Indonesia. Seperti Garudayana, Sudamala dan lain sebagainya.

Perupaan figur wayang yang digambarkan candi Sukuh dengan tokohtokoh yang ada seperti penggambaran lukisan wayang purwa di Desa Kamasan Bali. Demikian juga dengan wayang kulitnya, dilihat dari gestur, tipelogi wajah serta atribut yang digunakan. Beberapa penokohan wayang yang digambarkan di relief tersebut seperti makhluk surgawi (Dewa Krisna), kesatria (Bima), (Arjuna), Sudra (Twalen)/parekan dan lain-lainya. Perupaan figur relief di candi Sukuh dibandingkan dengan perupaan wayang kulit Bali. Lihat tabel 1.

Tabel 1. Perbandingan rupa relief candi Sukuh dengan wayang kulit Bali.

Sumber relief: chic-id.com (12-04-2018 :

$$
09.15 \text { wib) }
$$

Sumber wayang: balibeyond.com (2-04-
2018: 20.45 wib)

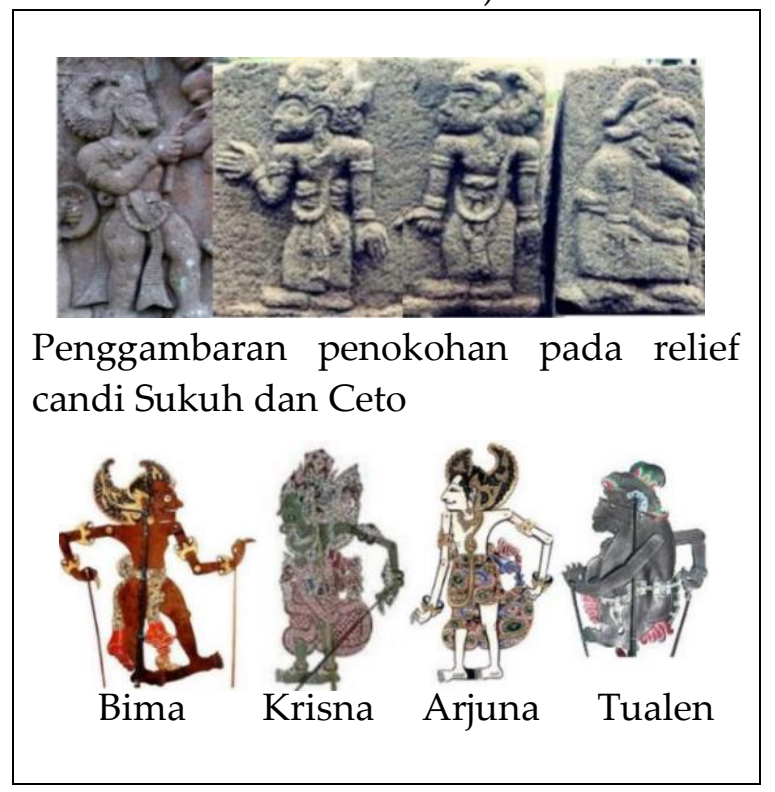

Melihat penggambaran tokoh wayang yang ada di candi Sukuh tersebut dibandingkan dengan rupa wayang kulit Bali tak jauh berbeda. Cara penggambaran wajah mengambil profil dari samping, badan dari depan penggunaan atribut seperti mahkota, hiasan leher (badong), hiasan tangan, memiliki kemiripan wayang kulit di Bali. Tokoh Dewa Krisna lebih lengkap penggunaan ragam hiasnya di wayang kulit dibandingkan pada relief, hiasan baju kusuma melengkapai punggung wayang. Tokoh panakawan yang digambarkan sangat mirip dan sampai sekarang tidak banyak berubah. Tokoh panakawan yang digambarkan tersebut di Bali disebut 'Twalen' : 'tua' yang 'len' berarti orang tua yang berbeda, walaupun digolongkan sebagai toloh sudra tetapi tokoh ini bisa melebihi tingkatan Dewa penuh kebijakan dan mawas diri. Twalen panakawan yang berada di pihak baik 'tengen' (kanan) digambarkan berbadan gemuk, dengan tutup kepala 'udeng' dan kuncir tipe mata sipit. Pasangan panakawan ini adalah Merdah dengan ciri khas hidung yang digambarkan bulat. Merdah berarti 
merendah atau suara pelan sebagai simbol rendah diri dan berbicara harus pelan dan hati-hati. Tentang panakawan ini dijelaskan lebih lanjut dalam Kitab Nawaruci karya Empu Siwamurti pada abad ke 15. Panakawan 'Twalen' dalam wayang purwa Jawa dikenal dengan 'Semar' yang selalu berpasangan dengan 'Gagakampuan' istilah di Balinya dikenal dengan 'Merdah'. (Sunarto, 2012 : 245).

Penggambaran penokohan kesatria Bima pada penggunaan kain yang sederhana mirip pada penggambaran wayang kulit, tetapi penggunaan hiasan leher sampai ke pinggang (naga wangsul) tidak dijumpai pada wayang kulit. Bima pada wayang kulit lebih sederhana hiasan leher yang digunakan biasanya ular belang demikian juga pada lukisan wayang. Tipelogi wajah menggunakan tipe mata 'dedeling' bulat mendelik, tokoh bima memiliki watak yang keras dan teguh

Penggambaran figur-figur wayang seperti wayang klasik Bali banyak terdapat juga di relief candi-candi Jawa Timuran seperti candi Penataran, candi Jago, candi Tegowangi, candi Singosari, candi Jawi, candi Surawana dan candi Kedaton. Penggambaran atau gaya yang digunakan pada candi-candi tersebut memang sudah melepaskan gaya candi yang ada di Jawa Tengah abad 7 dan $8 \mathrm{M}$. Pahatan relief lebih plat dengan ruangruang gambar yang lebih penuh dan bebas. Kecendrungan rupa relief mengarah bentuk primitif.

Pada candi Penataran memiliki tema cerita yang beragam, dari epos besar Mahabratha dan Ramayana juga terdapat kisah Panji dan Tantri dengan penggambaran rupa relief begitu plat.
Kisah perjalanan Rama merupakan cerita yang mendominasi dari cerita lainnya. Hadirnya tokoh-tokoh kesatria para pasukan Rama seperti Hanoman, Anggada, Subali, Jembawan dan tokoh lainnya digambarkan dengan figur manusia berkepala kera. Disamping penggambaran kera-kera itu sendiri. Penggambaran penokohan wayang Ramayana di relief tersebut dibandingkan dengan dengan tokoh wayang kulit Ramayana di Bali, terdapat unsur-unsur kesamaan dan kemiripan dalam pengungkapannya, seperti ditunjukan dalam tabel 2.

Tabel 2. Perbandingan rupa Hanoman pad relief Penataran dan gambar wayang kulit Bali

Sumber relief : maranata.ac.id (16-Juni$2018: 19.30 \mathrm{wib}$ )

Sumber gambar : blog.isi.dps.ac.id (16Juni-2018 : $20.15 \mathrm{wib}$ )

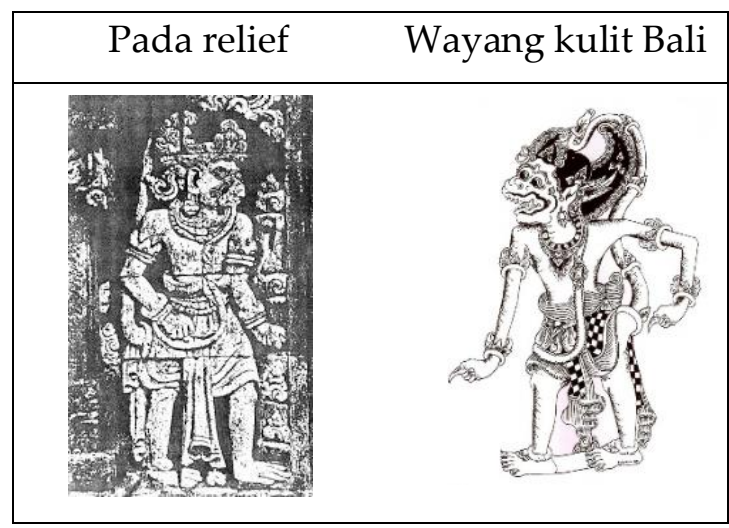

Tokoh kesatria Hanoman yang digambarkan pada wayang kulit Bali memiliki kedekatan dengan rupa yang ada di candi Penataran. Profil muka mengambil bentuk tiga perempat memperlihatkan bentuk kedua mata dengan jenis 'dedeling' (galak) dengan gestur muka sedikit berbeda, wayang kulit lebih menengadah sedangkan relief lebih merunduk. Penggambaran bentuk ekor sedikit berbeda pada bagian atas dibuat lebih melengkung ke arah 
mahkota sedangkan pada relief menjauhi. Menggunakan mahkota apitsurang memiliki dua lengkungan ke atas dan atribut perhiasaan yang hampir sama.

Kumpulan candi Jawa Timuran yang memiliki kedekatan perupaan dengan wayang klasik Bali dan memiliki tema cerita yang hampir sama yaitu Arjuna Wiwaha seperti candi Jago, candi Surawana, Kedaton, Jawi dan candi Tegowangi, demikian pula dengan candi Singosari yang merupakan geonologi lahirnya perubahan bentuk relief wayang di wilayah tersebut. Penggambaran tokoh-tokoh yang ada pada cerita tersebut memiliki kedekatan dan kemiripan seperti kita melihat wayang klasik dan lukisan Kamasan Bali.

Penggambaran tokoh dewi atau putri diambil dari relief candi Jago menunjukan gejala yang hampir sama baik itu dari profil, atribut serta hiasan yang dikenakan. Tokoh putri menggunakan tata rambut yang digulung ke atas (pepusungan) dengan hiasan rambut garuda mungkur. Bedanya hanya pada penggambaran uraian rambut yang menelusuri punggung belakang tidak kelihatan di relief. Demikian pula penggambaran brahmana (pendeta) pada relief candi Tegowangi yang memiliki memiliki kedekatan perupaan karakter pendeta pada wayang Bali, ditunjukan tabel 3.

Tabel 3. Perpandingan tokoh putrid an brahmana pada relief dan wayang

Sumber relief : wacana.co/( 4-April-2018 : $09.30 \mathrm{wib}$ ) dan afrikenz.blogspot.com
(16-Juni-2018 : $20: 30 \mathrm{wib})$

Sumber gambar : balibeyond.com (2-04$2018: 09: 35 \mathrm{wib})$

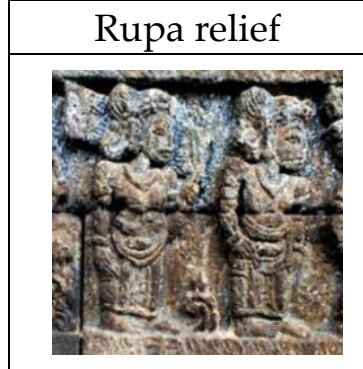

Dewi /Ratu

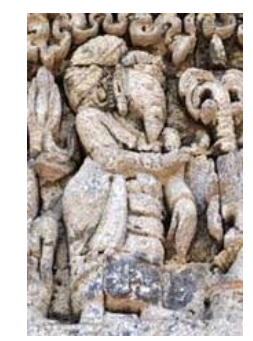

Pendeta/Brahmana

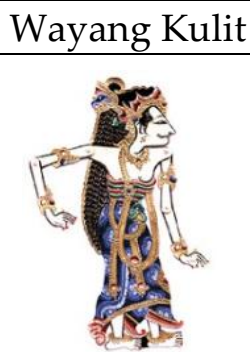

Dewi Drupadi

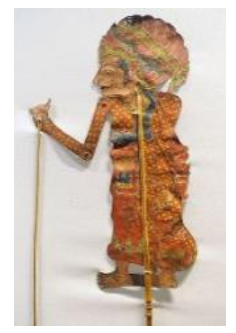

Begawan Bisma
Penggambaran penokohan golongan brahmana menggunakan mahkota (gelungan) yang disebut ' $k e t u$ ' menggunakan jubah atau baju yang menutupi sampai ujung tangan. Tipologi wajah menggunakan jenis mata gabahan yang terbalik. Untuk memberikan kesan kearifan dan kebijaksanaan. Figur yang digambarkan pada relief candi Tegowangi ini tidak jauh berbeda dengan penokohan pendeta (brahmana) pada wayang kulit Bali.

Figur-figur wayang yang digambarkan di relief-relief candi Jawa Timuran ini terlihat memiliki kemiripan seperti yang dipahatkan juga di candi Sukuh dan Ceto di Jawa Tengah. Cara penggambaran adegan per-adegan memiliki kesamaan seperti penggambaran lukisan wayang Kamasan di Bali. Dimana ruang tak ada ruang kosong selalu penuh dengan ragam hias. Panel atau urutan adegan peradegan dibatasi dengan ragam hias 
tumbuhan (patra), ragam hias awan dan batuan (baturan). Kadang-kadang dipisah juga dengan gambar bangunan. Pola pengungkapan demikian terjadi juga pada pembuatan lukisan wayang purwa pada kanvas di Bali.

Munculnya penggambaran seni bagunan yang menghiasi relief candi Jawa Timuran sebagai latar dan lanskap mengingatkan kita pada bentuk-bentuk bangunan Pura di Bali. Bentuk bangunan gerbang pura (candi), gerbang puri (istana raja), dan kori (gerbang rumah) serta bangunan-bangunan pemujaan yang ada di dalam komplek pura, memiliki kemiripan bentuk dengan tata tradisi arsitektur tradisional Bali. Demikian juga pembagian tata ruang atau denah, menunjukan kaidah-kaidah tata ruang yang digunakan para arsitektur tradisional (undagi) Bali sekarang, tabel 4.

Tabel 4. Perbandingan cara penggambaran pada relief dengan penggambaran lukisan wayang klasik Kamasan.

Sumbern relief wsfotografer.blogspot.co.id/(12-April$2018: 10.20$ wib)

Sumber gambar : balitoursclub.net/desakamasan( 4 April 2018 : 20.15 wib)

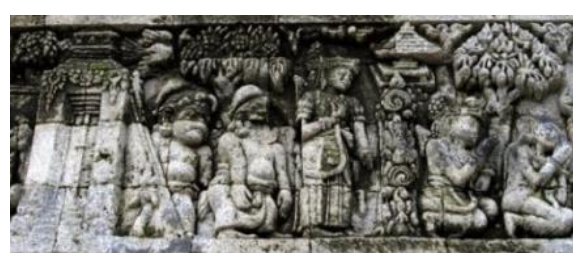

Cara pengungkapan pada relief

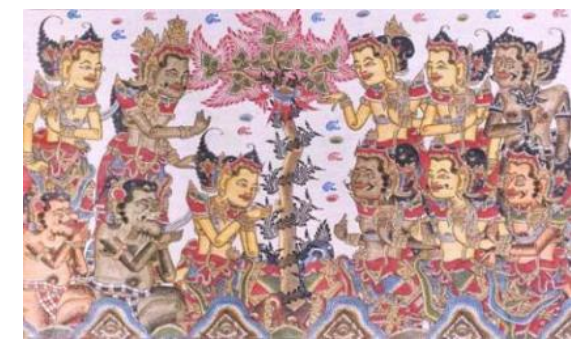

Lukisan wayang kamasan

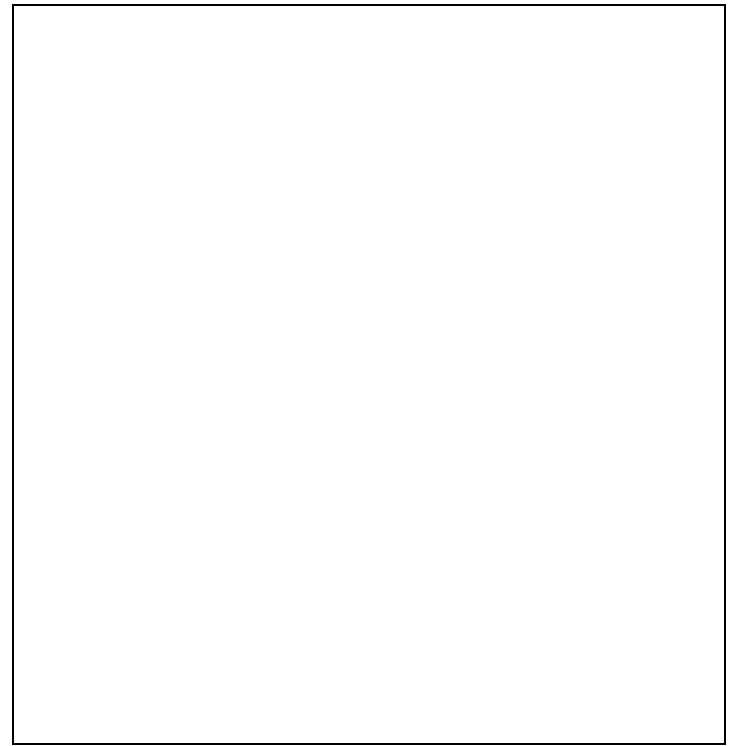

Munculnya tokoh-tokoh panakawan 'parekan' yang mengiringi tokoh-tokoh kesatria baik itu di pihak kanan 'tengen' maupun pihak kiri ' $k i w a$ ' pihak jahat, dan selalu berpasangan. Seperti Tualen dan Merdah di pihak kanan dan 'Delem' dan 'Sangut' di kiri. Tokoh panakawan ini hampir terdapat di candi Jawa Timur maupun Jawa Tengah. Tokoh panakawan harus berpasangan, dan kadang dapat hadir di semua cerita Mahabratha, Ramayana dan cerita Panji.

Kehadiran panakawan ini memberikan suatu gambaran atau simbol masyarakat bawah atau masyarakat yang tidak normal, bahwa aspirasi atau suara mereka akan kebenaran dan nasehat yang bijak dari golongan bawah. Dalam cerita panakawan ini sebagai penghibur para satria yang mengiring dalam melaksanakan tugas negara. Sering juga sebagai pemberi nasehat atau pun masukan pada tuannya.

Pada candi Penataran dan Jago terdapat juga penggambaran tokoh Panji, merupakan cerita raja-raja dengan latar belakang masa kerajaan Kediri dan Jenggala. Wayang kulit panji dikategorikan dalam wayang Arja dan Gambuh dengan tokoh utama Raden Panji 
menggunakan hiasan 'tekes', mahkota menyerupai topi walaupun atribut dan hiasannya lainnya sama dengan hiasan wayang umumnya. Secara gestur dan tipologi perwajahan termasuk jenis 'bagus manis' seperti tokoh Arjuna. Cerita Panji sudah ada pada jaman kerajaan Majapahit dan terus popular pada saat masuknya Islam. Cerita Panji meluas tidak hanya ada pada kesenian wayang juga meluas pada seni pertunjukan seni topeng yang tersebar di hampir di seluruh wilayah Jawa dan diperkirakan diciptakan oleh Sunan Giri (Riyanto, 2018 : 4). Lihat tabel 5.

Tabel 5. Perbandingan Figur Panji Sumber relief : wacana.co/( 4-April-2018 :21.05)

Sumber gambar : Covarobias, $1947: 237$

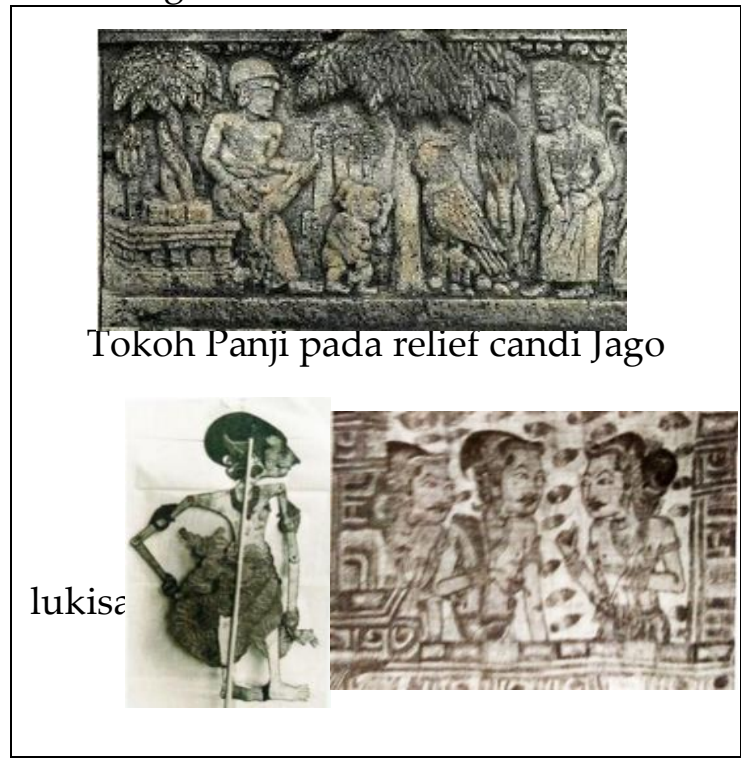

Penggambaran tokoh Panji pada relief candi Jago dibandingkan dengan wayang kulit Panji serta lukisan wayang Kamasan Bali. Terdapat kesamaan cara penggambaran baik dari segi figur, atribut serta aksesori yang lainnya memiliki kedekatan perupaan. Wayang kulit Panji sekarang ini jarang di pentaskan di Bali, tapi dia lebih sering dipentaskan pada seni pertunjukan lainnya seperti tari dan dramatari seperti
Gambuh, Arja dan Drama Gong.

Cerita lain yang juga dipahatkan pada candi Penataran adalah cerita tentang dongeng binatang atau fabel Dyah Tantri, semacam cerita 1001 malam dengan tokoh-tokoh utamanya berupa binatang. Cerita -cerita tersebut seperti : Pedanda Baka kisah seekor kura-kura dengan burung bangau. Lembu Nandaka, dan lain sebagainya. Penggambaran karakter binatang memiliki kemiripan dengan penggambaran binatang dalam pewayangan di Bali. Stilasi dan penggayaan rupa binatang kadangkadang dipadukan dengan pola hias atau motif yang di Bali dikenal dengan sebutan 'pepatran'

\section{KESIMPULAN}

Berdasarkan pemaparan diatas baik berdasarkan bukti tertulis maupun kedekatan visual bahwa kesenian wayang merupakan kesenian masyarakat prasejarah yang dalam perkembangannya, kesenian tersebut mendapatkan pengaruh unsur-unsur budaya luar. Mengingat letak strategis Indonesia terutama Jawa dan Bali sebagai lalu lintas perdagangan dunia atau jalur sutra. Pengaruh terbesar dan paling lama adalah India dengan unsur Hindu dan Buddha kemudian Cina, Persia dan bangsa Eropa lainnya.

Akulturasi budaya India tersebut bersinergi pada masa pemerintahan Kerajaaan Majapahit yang ada di Jawa. Kesenian wayang memperlihatkan bentuk Indonesianya, figur-figur wayang yang dipahatkan lebih pipih dengan langgam supranaturalistik dan primitif, Berbeda dengan langgam terdahulunya seperti di Borobudur dan Prambanan., 
dengan sumber cerita utama Epos Mahabratha dan Ramayana, demikian juga munculnya cerita fabel Dyah Tantri dan cerita raja-raja pada Panji, menjadi cerita utama dalam masa tersebut.

Keberadaan kesenian wayang di Bali dan Jawa memiliki sejarah yang hampir sama. Kesenian wayang lebih dahulu muncul di Jawa di dasarkan prasasti Balitung yang dikeluarkan oleh Raja Lokapala, setengah abad kemudian di kenalkan di Bali melalui ikatan persaudaraan oleh raja Udayana. Kemudian mengalami perkembangan yang pesat saat Bali di ditaklukan oleh kerajaan Majapahit hingga mundurnya kerajaan tersebut di Jawa. Kesenian Majapahit tetap diteruskan di Bali dan mencapai puncaknya pada Bali Hindu Klasik pada era Dalem Waturenggong. Masyarakat Bali mewarisi kesenian klasik yang dijalankan sampai sekarang sebagai kesenian tradisional. Bentuk rupa wayang yang diwarisakan tidak jauh berbeda dengan penggambaran wayang yang ada di relief-relief candi peninggalan kerajaan Majapahit baik yang ada di Jawa Tengah maupun di Jawa Timur.

Tanda-tanda dan gejala perupaan yang digambarkan pada relief-relief candi memiliki kemiripan seperti pada tata ungkap segi gestur, perwatakan, atribut, maupun aspek pengungkapan latar dan ragam hiasnya. Hal ini terlihat pada penggambaran pada lukisan wayang klasik yang ada di Desa Kamasan. Hanya saja pada lukisan wayang urutan membacanya dari bawah atau layer pertama.

Keberlangsungan perupaan wayang Majapahit di Bali, ini disebabkan masyarakat Bali masih memeluk agama
Hindu berserta tata aturan yang diwariskan dari kerajaan Majapahit. Berasimilasi dengan konsep kehidupan masyarakat Bali seperti 'Tri Hita Karenanya' dan Desa, Kala, Patranya. Tri Hita Karena yaitu tiga penyebab hidup bahagia yaitu selalu menjaga hubungan dengan Tuhan, hubungan sesama dan hubungan alam sekitarnya. Masyarakat berkesenian dalam kontek selalu dihubungkan dengan Hyang Pencipta. Kemudian Desa, Kala dan Patra yaitu keluwesan dan kelenturan dalam menghadapi tantangan jaman. Bagaimana masyarakat Bali dapat menyesuaikan kondisi dan menempatkan keseniannya pada tempat dan waktunya. Sehingga kesenian wayang tidak juga ketinggalan jaman.

Wayang sebagai suatu konvensi dalam kesenian tidak dipandang sebagai sesuatu yang selalu mengikat tapi dilihat sebagai sesuatu yang dinamis. Seniman atau juru wayang tahu betul akan hal tersebut, dimana batas-batas toleransi tradisi agar tidak ketinggalan jaman serta kreativitas seniman tidak mati dan terkukung. Adaptasi biasanya dilakukan pada pendukung pertunjukan sesuai dengan kemajuan teknologi serta menyisipkan karakter baru pada golongan rakyat atau pendamping punakawan.

Unsur cerita baru juga jarang ditemukan pada pertunjukan wayang kulit Bali, Mahabharata dan Ramayana sepertinya sudah mendarah daging dalam kehidupan sehingga sangat melekat di hati penggemarnya. Walaupun perkembangan wayang sekarang sudah mengikuti kemajuan dan perkembangan jaman, abad informasi dan teknologi, kesenian wayang klasik Bali tidak terlalu jauh bertransformasi. 


\section{Ucapan Terima Kasih}

Penulis mengucapkan terimakasih pada LPPM Universitas Telkom atas bantuan hibah dana peneltian internalnya. Demikian juga dengan narasumber seperti: Mangku Gede Pura Kehen di kabupaten Bangli. Dalang I Made Sija di Desa Bone Blahbatuh Gianyar Bali.

\section{REFERENSI}

\section{Artikel Jurnal}

Deny Yudo Wahyudi \& Slamet Sujud Purnawan Jati (2014). Relief Ari Darma di Candi Jago. Sejarah dan Budaya, Tahun Kedelapan, Nomor 2, Desember 2014.

Irfansyah, Piliang, Y.A. (2013). Perbandingan Kode Visual Pertunjukan Golek Sunda Tradisional dan Pertunjukan Golek Sunda dalam Media TV. Panggung, Vol. 2. No 2. 109-209.

R.Bambang Gatot Soebroto, (2012) Kajian estetika yang Beda Relief Candi Jawa Timur. Jurnal Arsitektur Universitas Bandar Lampung, JA! No.2 Vol.2

Riyanto. (2018) Perkembangan Wayang Alternatif di Bawah Hegomoni Wayang Kulit Purwa. Panggung Vol. 28 No.1. 1-15

Sunarto, (2012) Panakawan Wayang Kulit Purwa : Asal-Usul dan Konsep perwujudannya. Panggung, Vol. 22, No.3.225-350.

Nilotama, Sangayu ketut Laksemi. ( 2012). Konsep Simbolik Pada Lukisan Wayang Gaya Kamasan Dikaitkan dengan Konteks Arsitektur Bali. Dimensi. Vol 9-No2 September.

\section{Buku}

Ardika, I Wayan. Parimartha, I
Gede.Wirawan, A A Bagus. 2015. Sejarah Bali dari Prasejarah Hingga Modern. Udayana University Press. Bali. Indonesia.

Bandem, I Made, dan Rembang, Nyoman,(1983) Perkembangan Topeng Bali Sebagai Seni Pertunjukan, Proyek Penggalian Pembinaan Seni Klasik dan Tradisional dan Kesenian Baru, Pemda Tk. I Bali.

Covarrubias, Miguel. 2013. Pulau Bali, Temuan yang menakjubkan. Udayana University Press. Denpasar Bali.

Covarrubias, Miguel. (1947). The Island Of Bali. Alfred. A. Knopf. New York.

Hotl, Claire. (2000). Melacak Jejak Perkembangan Seni di Indonesia. Alih Bahasa: Dr. R.M.Soedarsono. Arti Line. Bandung.

Mulyono, Sri. (1989). Wayang AsalUsul, Filsafat dan Masa Depannya. CV. Haji Masagung.

Ratna, Nyoman Kutha. (2016). Metodologi Penelitian Kajian Budaya dan Ilmu Sosial Humaniora Pada Umumnya. Pustaka Pelajar (Cetakan II) Yogaykarta.

Soewardikoen, Didit Widiatmoko. Metode Penelitian Visual, Dari Seminar ke Tugas Akhir. Dinamika Komunika. Bandung Indonesia.

Sulasman, (2014). Metode Penelitian Sejarah. Pustaka Setia Bandung. Indonesia.

Tim Peneliti, (1999). Kamus Besar Bahasa Indonesia. Departemen Pendidikan dan Kebudayaan. Balai Pustaka. Jakarta Yudoseputro, Wiyoso. (2008). Jejak-Jejak Tradisi Bahasa Rupa Indonesia Lama. Yayasan Seni Visual Indonesia. Jakarta.

\section{Skripsi, Thesis, Desertasi, dan Laporan} Penelitian 
Etty Saringendyanti, (2008). Candi Sukuh dan Ceto di Kawasan Gunung Lawu Peranannya pada Abad 14-15M. Laporan Penelitian. Universitas Pejajaran.

Nilotoma, Sangayu Ketut Laksemi. (2013). Nilai Estetik Bale Kertha Gosa di Puri Semarapura Klungkung, Desertasi, FSRD-ITB.

Pratiwi, P. (2016). Makna Visual Relief Cerita Sri Tanjung Candi Penataran. Tugas Akhir Skripsi. ISI yogya.

Tim Penelitian. (1985). Monografi Bali, Pemerintah daerah tingkat I Bali.

Witari, Ni Nyoman. (2012). Tokoh Wayang Kulit Sangut dan Delem Sebagai Tokoh Kartun Editorial Harian Bali Post. Tesis, FSRD-ITB. 